\title{
PREDICTION OF STRENGTH AND SLUMP OF RICE HUSK ASH INCORPORATED HIGH-PERFORMANCE CONCRETE
}

\author{
Md. Nazrul Islam ${ }^{1}$, Muhammad Fauzi Mohd Zain ${ }^{2}$, Maslina Jamil ${ }^{3}$ \\ ${ }^{1}$ Department of Civil Engineering, Dhaka University of Engineering and Technology (DUET), \\ Gazipur, Gazipur-1700, Bangladesh \\ ${ }^{1,2,3}$ Faculty of Engineering and Built Environment, National University of Malaysia (UKM), \\ 43600 UKM Bangi, Selangor Darul Ehsan, Malaysia \\ E-mail: ${ }^{1}$ nazrul2100@yahoo.com (corresponding author)
}

Received 29 Jul. 2010; accepted 03 Mar. 2011

\begin{abstract}
This paper describes the development of statistical models to predict strength and slump of rice husk ash (RHA) incorporated high-performance concrete (HPC). Sixty samples of RHA incorporated HPC mixes having compressive strength range of 42-92 MPa and slump range of 170-245 mm were prepared and tested in the laboratory. These experimental data of sixty RHA incorporated HPC mixes were used to develop two models. Six variables namely water-tobinder ratio, cement content, RHA content, fine aggregate content, coarse aggregate content and superplasticizer content were selected to develop the models and ultimately to predict strength and slump of RHA incorporated HPC. The models were developed by regression analysis. Additional five HPC mixes were prepared with the same ingredients and tested under the same testing conditions to verify the ability of the proposed models to predict the responses. The results of the prediction of the models showed good agreement with the experimental data. Thus the developed models can be used to predict slump and 28-day compressive strength of RHA incorporated HPC. The research demonstrated that strength and slump of HPC could be successfully modeled using statistical analysis.
\end{abstract}

Keywords: high-performance concrete, rice husk ash, strength, slump, statistical model, regression analysis.

\section{Introduction}

High-performance concrete (HPC) is defined as concrete, which meets special performance and uniformity requirements that cannot always be achieved routinely by using conventional materials and normal mixing, placing and curing practices (Zia et al. 1991). The requirements may involve enhancements of characteristics such as placement and compaction without segregation, longterm mechanical properties, early-age strength, volume stability or service live in severe environments. HPC is a relatively new product and its characteristics differ from that of normal concrete (Zain et al. 2002).

HPC mixtures are usually more expensive than conventional concrete mixtures because they usually contain more cement, several chemical admixtures at higher dosage rates than for conventional concrete, and one or more supplementary cementitious materials (Simon 2003). As the cost of materials increases, optimizing concrete mixture proportions becomes more desirable. Furthermore, as the number of constituent materials increases, the problem of identifying optimal mixtures becomes increasingly complex. Not only are there more materials to consider, but there also are more potential interactions among materials. Combined with several performance criteria, the number of trial batches required to find optimal proportions using traditional methods could become prohibitive. HPC is a highly complex material and modeling its beha- vior is a difficult task (Yeh 1998). Therefore, there is a need to find new methods for prediction of HPC properties. Although several models were developed for prediction and optimization of concrete properties (Zain et al. 2002; Simon 2003; Yeh 1998; Saridemir 2009a, b; Bai et al. 2003; Tanyildizi 2009; Bilim et al. 2009; Özcan et al. 2009; Guang, Zong 2000; Kasperkiewics et al. 1995; Lai, Serra 1997; Lee 2003; Lim et al. 2004; Patel 2003; Jaśniok, Zybura 2009; Kamaitis 2008; Bai, Gailius 2009), none of these models includes rice husk ash (RHA) as a supplementary cementitious material in making HPC. Rice husk, an agricultural waste, constitutes about one fifth of the 500 million metric tons of rice produced annually in the world (Mehta 1989). Due to the growing environmental concern, and the need to conserve energy and resources for sustainable development, efforts have been made to burn the husks at controlled temperature and atmosphere, and to utilize the ash so produced as a building material (Columna 1974; Mehta 1977, 1989; Ismail, Waliuddin 1996; Zhang, Malhotra 1996; Jauberthie et al. 2000; Bui 2001; Nehdi et al. 2003; Agarwal 2006; de Sensale 2006; Chindaprasirt et al. 2007; Gastaldini et al. 2007; Giaccio et al. 2007; Saraswathy, Song 2007; Sata et al. 2007; Ganesan et al. 2008; Nair et al. 2008; de Sensale et al. 2008; Zain et al. 2011). The main concern of this study was to develop statistical models for predicting strength and slump of RHA incorporated HPC. 


\section{Material properties}

Ordinary Portland cement (Type I) was used that meets the ASTM C150 (2011) specifications. RHA used was produced in the laboratory. The chemical and physical properties of the cement and RHA are shown in Table 1. Natural river sand and crushed limestone were used as aggregates. The gradation of both fine and coarse aggregates met the ASTM C33 (2011) specification. The details of physical properties of both aggregates are shown in Table 2. Glenium $100 \mathrm{M}$ superplasticizer complying with the requirements of ASTM C494 (2011) and ASTM C1017 (2007) was used (solid content $=25.25 \%$ and specific gravity $=1.28)$. Normal tap water $(\mathrm{pH}=6.9)$ was used as mixing water and for curing.

Table 1. Chemical and physical properties of cement and rice husk ash (RHA)

\begin{tabular}{lcc}
\hline \multicolumn{1}{c}{ Property } & Cement & Rice Husk Ash \\
\hline $\mathrm{SiO}_{2}(\%)$ & 21.54 & 86.49 \\
$\mathrm{Al}_{2} \mathrm{O}_{3}(\%)$ & 5.99 & 0.01 \\
$\mathrm{CaO}(\%)$ & 65.3 & 0.50 \\
$\mathrm{MgO}(\%)$ & 0.77 & 0.13 \\
$\mathrm{MnO}(\%)$ & 0.01 & 0.07 \\
$\mathrm{P}_{2} \mathrm{O}_{5}(\%)$ & 0.31 & 0.69 \\
$\mathrm{SO}_{3}(\%)$ & 1.41 & - \\
$\mathrm{TiO}_{2}(\%)$ & 0.21 & - \\
$\mathrm{Fe}_{2} \mathrm{O}_{3}(\%)$ & 4.45 & 0.91 \\
$\mathrm{C}(\%)$ & 0.71 & 3.21 \\
$\mathrm{Loss}$ on ignition (LOI) (\%) & 1.06 & 8.83 \\
$\mathrm{Na}_{2} \mathrm{O}(\%)$ & - & 0.05 \\
$\mathrm{~K}_{2} \mathrm{O}(\%)$ & - & 2.7 \\
$\mathrm{Specific} \mathrm{gravity}$ & 3.16 & 2.00 \\
Specific surface area $\left(\mathrm{m}^{2} / \mathrm{kg}\right)$ & 402 & 183.3 \\
\hline
\end{tabular}

Table 2. Physical properties of fine and coarse aggregates

\begin{tabular}{lcc}
\hline \multicolumn{1}{c}{ Property } & $\begin{array}{c}\text { Fine } \\
\text { Aggregate }\end{array}$ & $\begin{array}{c}\text { Coarse } \\
\text { Aggregate }\end{array}$ \\
\hline Size $(\mathrm{mm})$ & $0-4.75$ & $4.75-19$ \\
Bulk specific gravity & 2.60 & 2.61 \\
Absorption (\%) & 1.47 & 0.82 \\
Fineness modulus & 3.04 & 6.68 \\
\hline
\end{tabular}

\section{Concrete mixes, specimen preparation and testing}

Sixty samples of RHA incorporated HPC mixes were prepared in the laboratory. Table 3 shows water-to-binder ratio (W/B), cement (C), rice husk ash (RHA), water (W), fine aggregate (FA), coarse aggregate (CA) and superplasticizer (SP) contents of these mixes.

A rotating pan-type mixer of $0.05 \mathrm{~m}^{3}$ capacity was used to mix concrete. Each batch included sufficient concrete for three slump tests and four $100 \times 200 \mathrm{~mm}$ cylinders for compressive strength test. The cylinders were fabricated in accordance with ASTM C192 (2007). To obtain adequate consolidation, the cylinders were rodded. The cylinders were covered with plastic and left in the molds for 24 hours, after which they were stripped and placed in limewater-filled curing tanks for moist curing at $23 \pm 2{ }^{\circ} \mathrm{C}$. Slump test of fresh concrete was carried out as per ASTM C143 (2010). Compressive strength tests (ASTM C39 2010) were conducted on the cylinders at the age of 28 days. In most cases, three cylinders were tested. A fourth test was performed in some cases if one result was significantly lower or higher than the others. Before testing, the cylinder ends were ground parallel to meet the ASTM C39 (2010) requirements using an end-grinding machine designed for this purpose. The average strength of three cylinders was reported as result of the test. Results of slump test (range: $170 \mathrm{~mm}$ to $245 \mathrm{~mm}$ ) and compressive strength test (range: 42.47 MPa to 92.21 MPa) are also shown in Table 3.

\section{Model development}

Six variables were selected to derive statistical models and ultimately to predict the properties of RHA incorporated HPC. The limits of the variables were decided by conducting some preliminary tests and from past experience. The notations used and limits of the variables are as follows:

$$
\begin{aligned}
&-x_{1}=\text { water-binder ratio (range: } 0.25-0.40) ; \\
&-\quad x_{2}= \text { cement, } \mathrm{kg} / \mathrm{m}^{3}(\text { range: } 378.8-553.8) ; \\
&-\quad x_{3}= \text { rice husk ash (RHA), } \mathrm{kg} / \mathrm{m}^{3} \text { (range: } 25.0- \\
&71.7) ; \\
&- x_{4}= \\
&-\quad x_{5}=\text { fine aggregate, } \left.\mathrm{kg} / \mathrm{m}^{3} \text { (range: } 543.8-720.7\right) ; \\
&1048.3) ; \\
&- x_{6}= \\
&
\end{aligned}
$$

The MINITAB statistical software (Minitab Inc. 2004) was used to derive two models by the least square approach. The general structure of the statistical model is as follows:

$$
y=\beta_{o}+\sum_{i=1}^{k} \beta_{i} x_{i}+\sum_{i=1}^{k} \beta_{i i} x_{i}^{2}+\sum_{i<j} \sum \beta_{i j} x_{i} x_{j}+\varepsilon,
$$

where: $y$ is the response; $x_{i}$ are the independent variables; $\beta_{o}$ is the independent term; $\beta_{i}, \beta_{i i}$ and $\beta_{i j}$ are the coefficients of independent variables and interactions, representing their contribution to the response; $\varepsilon$ is the random residual error term representing the effects of variables or higher order terms not considered in the model (Kutner et al. 2004).

The interaction between the six variables $\left(x_{i} x_{j}\right)$ and quadratic effect $\left(x_{i}^{2}\right)$ of variables were also considered in the proposed models as shown in Eq. (1). By trial and error, the best-fit models were identified from different probability distribution functions. The ' $t$ ' test was carried out to decide the statistical significance of variables. The null hypothesis was the presupposition that the true value of coefficient is zero. In other words, the variable or variables associated with that coefficient are statistically not significant and it has no influence on the response $y$. If the probability greater than ' $t$ statistic' is less than 0.05 $(5 \%)$, the null hypothesis (the coefficient value is zero) can be rejected and established that the variable or variables with the estimated coefficient has significant influence on the response. If the probability greater than ' $t$ statistic' is more than $0.05(5 \%)$, the null hypothesis can be accepted and it can be established that the variable or variables with estimated coefficient has no influence on 
Table 3. Mix proportions, slump and 28-day compressive strength of RHA incorporated HPC

\begin{tabular}{|c|c|c|c|c|c|c|c|c|c|}
\hline Mix No. & $\mathrm{W} / \mathrm{B}$ & $\begin{array}{c}\mathrm{C} \\
\left(\mathrm{kg} / \mathrm{m}^{3}\right)\end{array}$ & $\begin{array}{c}\text { RHA } \\
\left(\mathrm{kg} / \mathrm{m}^{3}\right)\end{array}$ & $\begin{array}{c}\mathrm{W} \\
\left(\mathrm{kg} / \mathrm{m}^{3}\right)\end{array}$ & $\begin{array}{c}\text { FA } \\
\left(\mathrm{kg} / \mathrm{m}^{3}\right)\end{array}$ & $\begin{array}{c}\mathrm{CA} \\
\left(\mathrm{kg} / \mathrm{m}^{3}\right)\end{array}$ & $\begin{array}{c}\mathrm{SP} \\
\left(1 / \mathrm{m}^{3}\right)\end{array}$ & $\begin{array}{l}\text { Slump } \\
(\mathrm{mm})\end{array}$ & $\begin{array}{c}\text { 28-day Strength } \\
(\mathrm{MPa})\end{array}$ \\
\hline 1 & 0.38 & 378.8 & 71.7 & 169.8 & 703.3 & 979.4 & 10.1 & 205 & 57.91 \\
\hline 2 & 0.40 & 382.3 & 59.8 & 176.1 & 682.4 & 1003.1 & 7.8 & 210 & 47.52 \\
\hline 3 & 0.39 & 387.3 & 55.4 & 171.7 & 681.6 & 1018.6 & 7.2 & 195 & 50.50 \\
\hline 4 & 0.39 & 384.9 & 35.2 & 164.8 & 720.7 & 1031.6 & 7.9 & 185 & 51.16 \\
\hline 5 & 0.40 & 411.9 & 25.7 & 176.2 & 694.4 & 1018.7 & 5.5 & 195 & 42.47 \\
\hline 6 & 0.40 & 407.3 & 33.3 & 175.5 & 690.9 & 1017.7 & 7.0 & 195 & 56.68 \\
\hline 7 & 0.40 & 385.1 & 55.4 & 176.5 & 683.5 & 1006.7 & 10 & 195 & 50.69 \\
\hline 8 & 0.40 & 395.7 & 48.8 & 178.0 & 684.8 & 1014.0 & 4.3 & 200 & 59.86 \\
\hline 9 & 0.40 & 393.7 & 51.8 & 178.4 & 683.9 & 1014.0 & 4.2 & 195 & 58.48 \\
\hline 10 & 0.35 & 400.4 & 68.1 & 162.7 & 693.5 & 984.4 & 14.1 & 217 & 45.61 \\
\hline 11 & 0.37 & 405.6 & 58.9 & 170.3 & 669.5 & 1005.6 & 10.7 & 200 & 55.43 \\
\hline 12 & 0.35 & 408.5 & 54.7 & 162.7 & 670.6 & 1030.2 & 9.6 & 200 & 54.52 \\
\hline 13 & 0.36 & 404.9 & 34.5 & 156.9 & 708.1 & 1041.4 & 11.0 & 195 & 55.79 \\
\hline 14 & 0.36 & 435.5 & 25.7 & 168.2 & 679.4 & 1028.7 & 8.3 & 195 & 55.11 \\
\hline 15 & 0.36 & 435.9 & 32.8 & 169.1 & 672.0 & 1027.5 & 9.0 & 200 & 59.39 \\
\hline 16 & 0.36 & 427.2 & 41.4 & 169.1 & 667.8 & 1021.2 & 11.4 & 200 & 56.04 \\
\hline 17 & 0.36 & 414.8 & 53.8 & 169.1 & 661.1 & 1010.8 & 15.7 & 210 & 51.55 \\
\hline 18 & 0.36 & 419.4 & 48.3 & 168.8 & 672.3 & 1026.8 & 5.43 & 210 & 70.59 \\
\hline 19 & 0.36 & 415.6 & 51.6 & 168.6 & 672.2 & 1025.9 & 7.1 & 210 & 70.45 \\
\hline 20 & 0.36 & 415.2 & 43.2 & 165.4 & 685.5 & 1034.3 & 6.2 & 210 & 70.95 \\
\hline 21 & 0.32 & 419.7 & 64.6 & 156.1 & 683.7 & 986.4 & 19.4 & 210 & 48.27 \\
\hline 22 & 0.34 & 428.2 & 57.9 & 165.2 & 656.2 & 1005.9 & 14.2 & 225 & 52.69 \\
\hline 23 & 0.32 & 429.4 & 54.0 & 154.7 & 657.0 & 1035.6 & 14.6 & 200 & 50.84 \\
\hline 24 & 0.33 & 424.3 & 33.7 & 149.9 & 693.6 & 1046.0 & 16.0 & 205 & 65.46 \\
\hline 25 & 0.33 & 458.6 & 25.6 & 161.0 & 663.8 & 1035.5 & 11.1 & 195 & 53.03 \\
\hline 26 & 0.33 & 464.4 & 32.1 & 162.6 & 647.9 & 1026.2 & 16.6 & 210 & 59.69 \\
\hline 27 & 0.33 & 456.8 & 39.7 & 162.6 & 644.9 & 1021.5 & 18.2 & 210 & 57.33 \\
\hline 28 & 0.33 & 444.7 & 51.8 & 162.6 & 636.2 & 1007.8 & 24.5 & 210 & 52.39 \\
\hline 29 & 0.33 & 442.8 & 47.8 & 160.6 & 659.1 & 1036.4 & 9.3 & 215 & 73.73 \\
\hline 30 & 0.33 & 438.4 & 42.4 & 157.4 & 671.5 & 1043.0 & 9.4 & 220 & 74.14 \\
\hline 31 & 0.30 & 437.1 & 61.3 & 149.8 & 676.6 & 989.9 & 23.3 & 230 & 52.34 \\
\hline 32 & 0.32 & 450.4 & 56.7 & 160.6 & 642.1 & 1004.1 & 18.5 & 235 & 66.88 \\
\hline 33 & 0.29 & 450.1 & 53.0 & 147.6 & 638.8 & 1032.2 & 18.7 & 200 & 53.10 \\
\hline 34 & 0.30 & 443.5 & 32.8 & 143.6 & 678.8 & 1048.3 & 21.5 & 180 & 74.70 \\
\hline 35 & 0.30 & 481.6 & 25.5 & 154.6 & 647.5 & 1039.0 & 17.7 & 230 & 61.68 \\
\hline 36 & 0.30 & 493.4 & 31.3 & 156.5 & 621.5 & 1018.4 & 27.0 & 220 & 62.07 \\
\hline 37 & 0.30 & 486.9 & 37.7 & 156.5 & 620.8 & 1017.2 & 26.5 & 210 & 61.39 \\
\hline 38 & 0.30 & 475.1 & 49.5 & 156.5 & 608.6 & 997.3 & 36.7 & 220 & 64.57 \\
\hline 39 & 0.30 & 466.4 & 47.1 & 153.2 & 645.0 & 1043.0 & 13.1 & 230 & 85.32 \\
\hline 40 & 0.30 & 458.9 & 50.7 & 152.1 & 644.8 & 1037.9 & 16.2 & 220 & 83.43 \\
\hline 41 & 0.30 & 461.7 & 41.4 & 150.1 & 656.4 & 1048.3 & 13.4 & 220 & 81.77 \\
\hline 42 & 0.30 & 472.4 & 55.3 & 156.3 & 627.3 & 1000.0 & 23.8 & 210 & 68.72 \\
\hline 43 & 0.27 & 471.0 & 52.0 & 141.0 & 622.5 & 1030.0 & 23.9 & 210 & 57.48 \\
\hline 44 & 0.28 & 462.7 & 31.8 & 137.8 & 662.3 & 1046.5 & 28.7 & 170 & 56.64 \\
\hline 45 & 0.28 & 504.9 & 25.2 & 148.6 & 627.6 & 1035.0 & 25.6 & 200 & 64.95 \\
\hline 46 & 0.27 & 523.0 & 30.3 & 150.9 & 598.3 & 1013.3 & 34.5 & 210 & 65.33 \\
\hline 47 & 0.27 & 517.9 & 35.4 & 150.9 & 591.4 & 1001.7 & 40.7 & 210 & 63.08 \\
\hline 48 & 0.27 & 506.5 & 46.8 & 141.0 & 579.1 & 980.8 & 51.4 & 210 & 60.28 \\
\hline 49 & 0.27 & 490.4 & 46.2 & 146.4 & 629.6 & 1046.2 & 19.4 & 230 & 84.98 \\
\hline 50 & 0.27 & 480.9 & 50.1 & 144.8 & 628.6 & 1037.8 & 23.0 & 230 & 80.75 \\
\hline 51 & 0.28 & 494.4 & 53.8 & 152.4 & 611.3 & 993.3 & 30.3 & 205 & 65.31 \\
\hline 52 & 0.25 & 492.2 & 50.8 & 134.9 & 609.1 & 1031.5 & 28.6 & 205 & 61.94 \\
\hline 53 & 0.26 & 481.9 & 30.8 & 132.4 & 643.6 & 1039.8 & 38.3 & 170 & 67.07 \\
\hline 54 & 0.25 & 528.5 & 25.0 & 143.0 & 604.6 & 1024.1 & 36.9 & 200 & 66.56 \\
\hline 55 & 0.25 & 553.8 & 29.1 & 145.6 & 567.4 & 992.9 & 50.4 & 200 & 66.50 \\
\hline 56 & 0.25 & 550.1 & 32.8 & 145.6 & 559.4 & 978.8 & 58.2 & 200 & 67.41 \\
\hline 57 & 0.25 & 539.2 & 43.6 & 145.6 & 543.8 & 951.6 & 72.6 & 190 & 45.58 \\
\hline 58 & 0.25 & 515.0 & 45.1 & 140.0 & 612.5 & 1045.4 & 28.6 & 240 & 91.55 \\
\hline 59 & 0.25 & 503.4 & 49.4 & 138.1 & 605.2 & 1024.4 & 37.1 & 245 & 77.70 \\
\hline 60 & 0.25 & 509.8 & 39.1 & 137.2 & 617.0 & 1039.9 & 30.7 & 240 & 92.21 \\
\hline
\end{tabular}

W/B: water-to-binder ratio; C: cement; RHA: rice husk ash; W: water; FA: fine aggregate; CA: coarse aggregate; SP: superplasticizer. 
the response and hence that variable or variables cannot be included in the model. In the proposed models, the probability greater than 't statistic' was found less than 0.05 . This signifies that there is less than $5 \%$ probability that the contribution of a given variable with the respective coefficient to the tested response exceeds the value of the specified estimated coefficient. A possible higher value of determination coefficient $\left(\mathrm{R}^{2}\right)$ was considered while selecting the proposed models. After many trials with MINITAB software, best-fit two models were found out for HPC properties e.g., compressive strength and slump as described in the following sections.

\subsection{Model 1: 28-day compressive strength}

In design and quality control of concrete, 28-day compressive strength is normally specified. The 28 -day compressive strength of concrete determined by a standard uniaxial compression test is universally accepted as a greater index of concrete strength (Patel 2003). Hence the 28-day compressive strength model was selected as a dependent variable of the model to evaluate the quality of RHA incorporated HPC.

The proposed 28-day strength model is:

$$
\begin{aligned}
y_{1}=- & 6018+7040 x_{1}+2.49 x_{2}+3.16 x_{3}+5 x_{4}+x_{5}+ \\
& 89.1 x_{6}-0.0902 x_{6}^{2}-8.47 x_{1} x_{4}-38.6 x_{1} x_{6}- \\
& 0.0484 x_{2} x_{6}-0.0497 x_{3} x_{6}-0.0743 x_{4} x_{6} .
\end{aligned}
$$

The statistical details of the model are presented in Table 4. The model is fit in normal (Gaussian) probability distribution function. All the six variables such as waterbinder ratio $\left(x_{1}\right)$, cement $\left(x_{2}\right)$, RHA $\left(x_{3}\right)$, fine aggregate $\left(x_{4}\right)$, coarse aggregate $\left(x_{5}\right)$ and superplasticizer $\left(x_{6}\right)$ have direct influence on the response (28-day compressive strength, $y_{1}$ ). Some variables are interacting with each other. Some of them have positive influence and some of them have negative influence on the response. The $R^{2}$ value is $85.3 \%$ which is an indication of reasonably good fitness. From the results of ANOVA analysis, it appears that the probability greater than " $F$ statistic" (Fisher statistic) is less than 0.0005 (Table 4). The model is highly statistically significant with confidence level more than $99.95 \%$. All the variables were also tested individually for 't statistic'. The probability greater than 't statistic' for intercept, all variables, and their interaction are indicated in Table 5 . The probability greater than 't statistic' for all variables is found to be less than 0.006 (confidence level more than $99.4 \%$ ). Therefore, all the variables indicated in the model are statistically significant and have influence on the 28-day compressive strength.

Table 4. Summary statistics of strength and slump models

\begin{tabular}{lccccc}
\hline Model & RMSE & $\begin{array}{c}\text { R-Sq } \\
\text { (\%) }\end{array}$ & $\begin{array}{c}\text { R-Sq (adj) } \\
\text { (\%) }\end{array}$ & $\begin{array}{c}\text { F-value of } \\
\text { ANOVA }\end{array}$ & $\begin{array}{c}\text { p-value of } \\
\text { ANOVA }\end{array}$ \\
\hline $\begin{array}{l}\text { 28-day } \\
\text { strength }\end{array}$ & 4.96336 & 85.3 & 81.6 & 22.80 & 0.000 \\
Slump & 7.21339 & 84.1 & 78.7 & 15.49 & 0.000 \\
\hline
\end{tabular}

RMSE: root mean square error; R-Sq: R-squared; R-Sq (adj): R-squared (adjusted); ANOVA: analysis of variance.
Table 5. Model terms and their significance of the 28-day strength model

\begin{tabular}{ccccc}
\hline Predictor & Coefficient & SE Coefficient & t statistic & p-value \\
\hline Constant & -6018 & 1027 & -5.86 & 0.000 \\
$x_{1}$ & 7040 & 1807 & 3.89 & 0.000 \\
$x_{2}$ & 2.4898 & 0.3741 & 6.66 & 0.000 \\
$x_{3}$ & 3.1630 & 0.4378 & 7.22 & 0.000 \\
$x_{4}$ & 4.995 & 1.168 & 4.28 & 0.000 \\
$x_{5}$ & 1.0045 & 0.1057 & 9.50 & 0.000 \\
$x_{6}$ & 89.08 & 24.09 & 3.70 & 0.001 \\
$x_{6}{ }^{2}$ & -0.09016 & 0.02685 & -3.36 & 0.002 \\
$x_{1} x_{4}$ & -8.469 & 2.489 & -3.40 & 0.001 \\
$x_{1} x_{6}$ & -38.60 & 10.58 & -3.65 & 0.001 \\
$x_{2} x_{6}$ & -0.04838 & 0.01502 & -3.22 & 0.002 \\
$x_{3} x_{6}$ & -0.04965 & 0.01719 & -2.89 & 0.006 \\
$x_{4} x_{6}$ & -0.07433 & 0.02018 & -3.68 & 0.001 \\
\hline
\end{tabular}

Fig. 1 shows the residual plot of the compressive strength model. The figure shows that the errors are independent. The residuals in the plot appear to be randomly scattered about zero. The other assumptions of regression analysis are also satisfied. The adjusted correlation coefficient is $81.6 \%$ (Table 4 ), which indicates a very good fit. The root mean square error is 4.96 , which is also an indication of accuracy of the model fit. The model is significant as can be seen from the significance value that is very close to zero.

\subsection{Model 2: slump}

The slump is one of the most important properties of HPC. If the slump of fresh concrete is between 180 and $220 \mathrm{~mm}$ without any segregation, the concrete can be qualified for HPC. Of course, other fresh concrete tests are also important to evaluate thoroughly the fresh HPC properties. However, one can take decision from slump test, if other test set-ups are not available.

The proposed slump model is:

$$
\begin{aligned}
y_{2}= & 1686+103595 x_{1}-41.8 x_{2}+2.3 x_{3}-209 x_{4}+ \\
& 114 x_{5}-27086 x_{1}^{2}+0.0604 x_{4}^{2}-0.0707 x_{5}^{2}- \\
& 66.4 x_{1} x_{2}-123 x_{1} x_{3}-49.4 x_{1} x_{5}+0.0997 x_{2} x_{4}+ \\
& 0.182 x_{3} x_{4}-0.0764 x_{3} x_{5}+0.0770 x_{4} x_{5} .
\end{aligned}
$$

The statistical details of this model are also presented in Table 4. The model was fit in normal (Gaussian) probability distribution function. Some of the variables have positive influence and some have negative influence on the response (slump, $y_{2}$ ). The $\mathrm{R}^{2}$ value is $84.1 \%$, which indicates reasonably good fitness. From the results of ANOVA analysis (Table 4), it appears that the probability greater than ' $F$ statistic' (Fisher statistic) is less than 0.0005 . The model is highly statistically significant with a confidence level more than $99.95 \%$. All the variables were also tested individually for 't statistic' (Table 6). It can be observed from Table 6 that the 'probability greater than t' for RHA $\left(x_{3}\right)$ is greater than 0.05 . It is still included in the model to maintain the hierarchy of the model terms. Hierarchical terms are linear terms that may be insignificant by themselves but are part of significant higher order terms. 


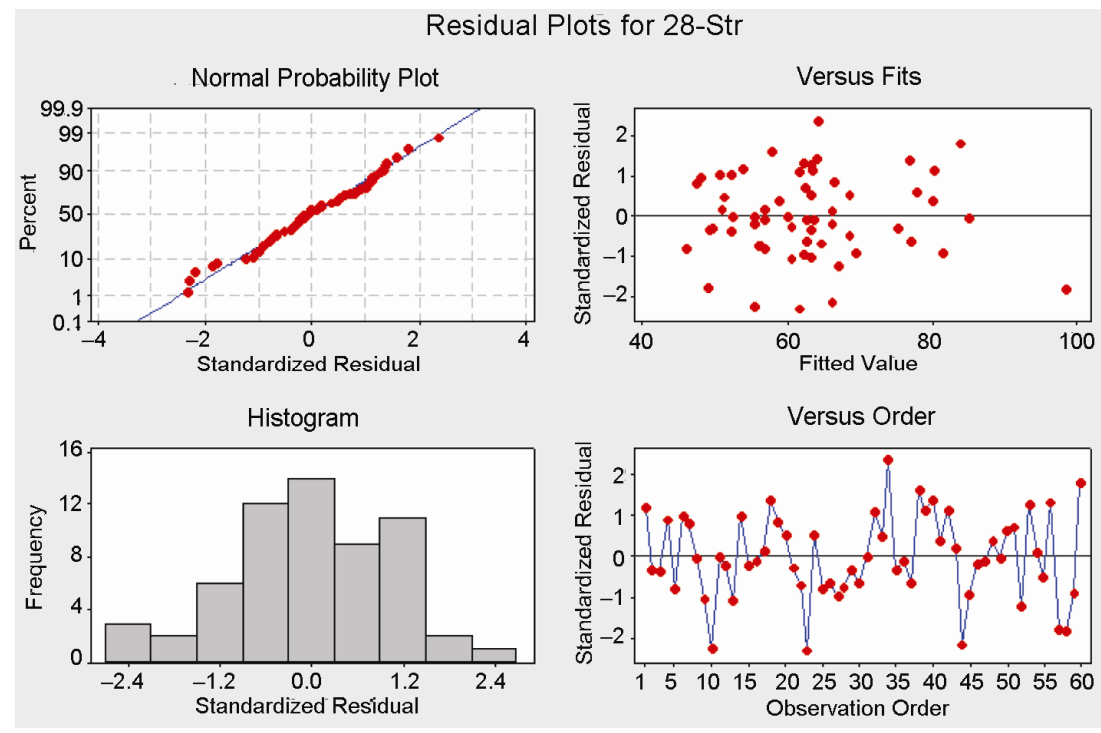

Fig. 1. Residual plots of the 28-day strength model

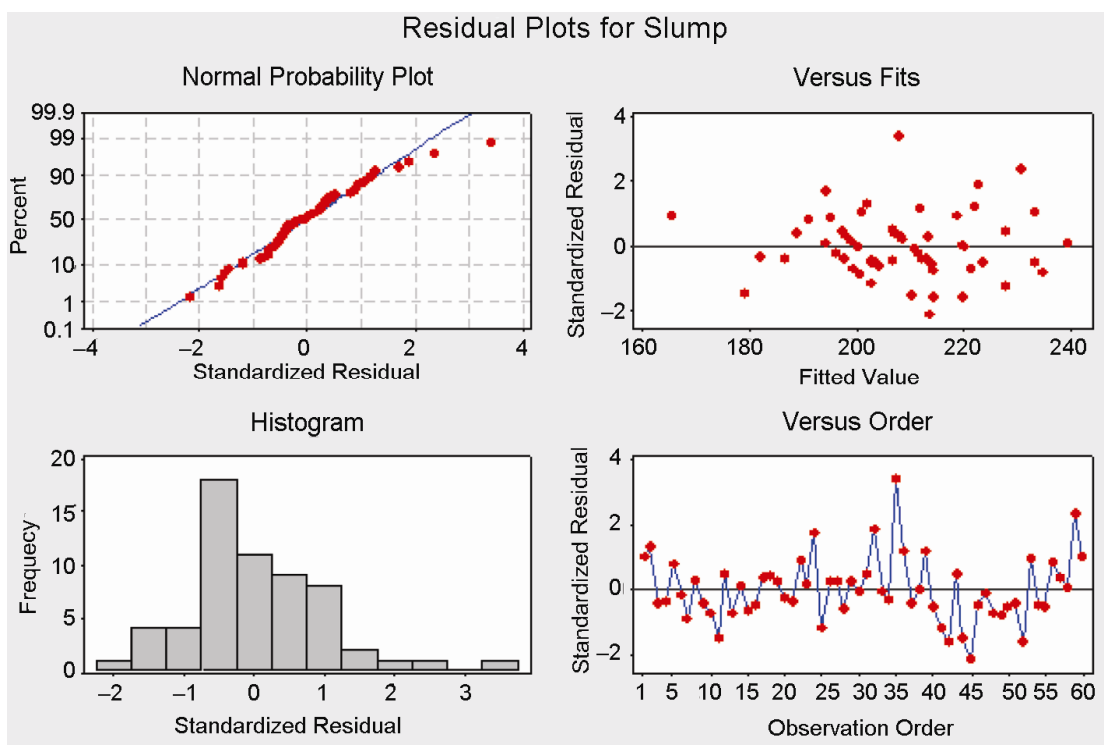

Fig. 2. Residual plots of the slump model

Table 6. Model terms and their significance of the slump model

\begin{tabular}{ccccc}
\hline Predictor & Coefficient & $\begin{array}{c}\mathrm{SE} \\
\text { Coefficient }\end{array}$ & $\begin{array}{c}\mathrm{t} \\
\text { statistic }\end{array}$ & $\mathrm{p}$-value \\
\hline Constant & 1686 & 6069 & 0.28 & 0.783 \\
$x_{1}$ & 103595 & 17150 & 6.04 & 0.000 \\
$x_{2}$ & -41.806 & 6.575 & -6.36 & 0.000 \\
$x_{3}$ & 2.26 & 19.78 & 0.11 & 0.910 \\
$x_{4}$ & -208.88 & 31.71 & -6.59 & 0.000 \\
$x_{5}$ & 113.79 & 21.50 & 5.29 & 0.000 \\
$x_{1}{ }^{2}$ & -27086 & 4540 & -5.97 & 0.000 \\
$x_{4}{ }^{2}$ & 0.060370 & 0.009657 & 6.25 & 0.000 \\
$x_{5}{ }^{2}$ & -0.07066 & 0.01379 & -5.12 & 0.000 \\
$x_{1} x_{2}$ & -66.44 & 10.15 & -6.54 & 0.000 \\
$x_{1} x_{3}$ & -123.13 & 23.27 & -5.29 & 0.000 \\
$x_{1} x_{5}$ & -49.38 & 10.10 & -4.89 & 0.000 \\
\hline
\end{tabular}

A hierarchical model allows for conversion of models between different sets of units (for a model involving temperature, conversion from $\mathrm{F}$ to $\mathrm{C}$, for example) (Simon 2003). All the variables in the model are statistically significant and have influence on the slump.

Fig. 2 shows the residual plot of the slump model. The figure shows that the errors are independent. The residuals appear to be randomly scattered about zero. The other assumptions of regression analysis are also satisfied. The adjusted correlation coefficient is $78.7 \%$ (Table 4), which indicates a good fit. The root mean square error is 7.21, which is also an indication of a good fit of the model. The model is significant as can be seen from the significance value that is very close to zero. 
Table 7. Mix proportion, slump and strength data for validation of the models

\begin{tabular}{cccccccccc}
\hline Mix No. & W/B & $\begin{array}{c}\text { C } \\
\left(\mathrm{kg} / \mathrm{m}^{3}\right)\end{array}$ & $\begin{array}{c}\text { RHA } \\
\left(\mathrm{kg} / \mathrm{m}^{3}\right)\end{array}$ & $\begin{array}{c}\text { W } \\
\left(\mathrm{kg} / \mathrm{m}^{3}\right)\end{array}$ & $\begin{array}{c}\text { FA } \\
\left(\mathrm{kg} / \mathrm{m}^{3}\right)\end{array}$ & $\begin{array}{c}\mathrm{CA} \\
\left(\mathrm{kg} / \mathrm{m}^{3}\right)\end{array}$ & $\begin{array}{c}\mathrm{SP} \\
\left(\mathrm{l} / \mathrm{m}^{3}\right)\end{array}$ & $\begin{array}{c}\text { Slump } \\
(\mathrm{mm})\end{array}$ & $\begin{array}{c}28 \text {-day Strength } \\
(\mathrm{MPa})\end{array}$ \\
\hline 1 & 0.40 & 397.7 & 42.8 & 176.5 & 689.0 & 1014.7 & 7.1 & 187 & 54.53 \\
2 & 0.40 & 391.7 & 43.8 & 174.5 & 698.5 & 1021.7 & 4.2 & 195 & 56.65 \\
3 & 0.33 & 437.3 & 51.2 & 159.9 & 659.5 & 1034.2 & 10.8 & 215 & 69.95 \\
4 & 0.28 & 453.0 & 58.7 & 143.9 & 661.8 & 980.4 & 35.1 & 222 & 55.02 \\
5 & 0.27 & 485.5 & 10.3 & 143.4 & 639.2 & 1049.0 & 19.5 & 213 & 66.00 \\
\hline
\end{tabular}

W/B: water-to-binder ratio; C: cement; RHA: rice husk ash; W: water; FA: fine aggregate; CA: coarse aggregate; SP: superplasticizer.

Table 8. Comparison of experimental and predicted values of strength and slump for the data of Table 7

\begin{tabular}{|c|c|c|c|c|c|c|}
\hline \multirow{2}{*}{$\begin{array}{l}\text { Mix } \\
\text { No. }\end{array}$} & \multicolumn{2}{|c|}{ Strength $(\mathrm{MPa})$} & \multicolumn{2}{|c|}{ Slump (mm) } & \multicolumn{2}{|c|}{ Variation (\%) } \\
\hline & Experiment & Prediction & Experiment & Prediction & Slump & Strength \\
\hline 1 & 54.5 & 52.0 & 187 & 194.6 & -4.06 & 4.59 \\
\hline 2 & 56.6 & 54.1 & 195 & 196.3 & -0.67 & 4.41 \\
\hline 3 & 69.9 & 69.4 & 215 & 215.6 & -0.28 & 0.79 \\
\hline 4 & 55.0 & 53.6 & 222 & 213.6 & 3.78 & 2.55 \\
\hline 5 & 66.0 & 62.9 & 213 & 203.2 & 4.60 & 4.70 \\
\hline
\end{tabular}

\section{Model validation}

Five additional mixtures were prepared and tested with the same ingredients to verify the ability of the proposed models to predict the responses. Table 7 shows the quantities of the ingredients, 28-day strength and slump of these five concrete mixes. The slump and the 28-day compressive strength were measured in the laboratory and compared with those of the prediction by the respective models. The experimental and model predicted values of slump and 28-day compressive strength are shown in Table 8. The tests were carried out with the same materials and under the same testing conditions. Table 8 shows that the variations among model predicted and experimental values for slump and strength were not significant, which is an indication that the models predict 28-day strength and slump with reasonable accuracy.

\section{Limitations of the models}

The proposed statistical models for prediction of strength and slump of RHA incorporated HPC were derived from sixty HPC mixes with ordinary portland cement (ASTM Type I), rice husk ash (specific gravity $=2.0$, specific surface area $=183.3 \mathrm{~m}^{2} / \mathrm{kg}$ ), natural river sand (specific gravity $=2.6$, absorption $=1.47 \%$, fineness modulus $=$ 3.04 ), crushed lime stone (specific gravity $=2.61$, absorption $=0.82 \%$, fineness modulus $=6.68$, maximum size $=$ $19 \mathrm{~mm}$ ), and Glenium $100 \mathrm{M}$ superplasticizer complying with the requirements of ASTM C494 (2011) and ASTM C1072 (2011) (solid content $=25.25 \%$ and specific gravity $=1.28)$. The models predict strength and slump with acceptable accuracy for ranges of mix proportions as shown in Table 3 (water-binder ratio: 0.25-0.40, cement: $378.8-553.8 \mathrm{~kg} / \mathrm{m}^{3}$, rice husk ash: $25.0-71.7 \mathrm{~kg} / \mathrm{m}^{3}$, fine aggregate: $543.8-720.7 \mathrm{~kg} / \mathrm{m}^{3}$, coarse aggregate: $951.6-$ $1048.3 \mathrm{~kg} / \mathrm{m}^{3}$, superplasticizer: $\left.4.2-72.6 \mathrm{l} / \mathrm{m}^{3}\right)$. It is very important to note that, similar to other statistical models, the derived models are material specific i.e., depended on material properties and mix proportions. The absolute responses from the models can differ if either the properties of materials or mix proportions vary considerably from the material properties and mix proportions used to derive the models. However, the models can still be useful for prediction of strength and slump when presented with different sets of materials and mix proportions.

\section{Summary and conclusion}

Using statistical regression analysis, two models for prediction of strength and slump of RHA incorporated HPC were developed. The best models for strength and slump were chosen by trial and error.

The proposed 28-day strength model:

Strength

$$
\begin{aligned}
28 d & -6018+7040 *\left(\frac{W}{B}\right)+2.49 * C+3.16 * R H A+ \\
& 5 * F A+C A+89.1 * S P-0.0902 * S P^{2}-8.47 * \\
& \left(\frac{W}{B}\right) * F A-38.6 *\left(\frac{W}{B}\right) * S P-0.0484 * C * S P- \\
& 0.0497 * R H A * S P-0.0743 * F A^{*} S P .
\end{aligned}
$$

The proposed slump model:

Slump

$$
\begin{aligned}
= & 1686+103595 *\left(\frac{W}{B}\right)-41.8 * C+2.3 * R H A- \\
& 209 * F A+114 * C A-27086 *\left(\frac{W}{B}\right)^{2}+0.0604 * \\
& F A^{2}-0.0707 * C A^{2}-66.4 *\left(\frac{W}{B}\right) * C-123^{*} \\
& \left(\frac{W}{B}\right) * R H A-49.4 *\left(\frac{W}{B}\right) * C A+0.0997 * C^{*} \\
& F A+0.182 * R H A^{*} F A-0.0764 * R H A^{*} C A+ \\
& 0.0770 * F A^{*} C A .
\end{aligned}
$$


It was found from the ANOVA analysis that all the six selected variables i.e., water-binder ratio $(\mathrm{W} / \mathrm{B})$, cement (C) content, rice husk ash (RHA) content, fine aggregate (FA) content, coarse aggregate (CA) content, and superplasticizer (SP) content are statistically significant and have direct influence on strength of RHA incorporated HPC. On the other hand, water-binder ratio, cement content, fine aggregate content and coarse aggregate content have significant influence on slump of RHA incorporated HPC.

The proposed models can be used to predict strength and slump of RHA incorporated HPC. Developed models were evaluated and the results of prediction were reasonably accurate. Similar to other statistical prediction models, the proposed models are depended on material properties and mix proportions. The absolute value of the predicted strength and slump may not be the same if different sets of materials are used. However, the models can still be useful for prediction of strength and slump when presented with different sets of materials and mix proportions. RHA incorporated HPC reduces use of cement in concrete, consumes waste, and increases durability of concrete. Thus, these models can be useful as tools for sustainable development because they can substantially reduce time, effort, and cost associated with selection of trial batches of HPC.

\section{Acknowledgements}

The research work reported in this paper was funded by the Ministry of Science, Technology and Innovation, Malaysia and Universiti Kebangsaan Malaysia (UKM). Materials were supplied by Ready Mixed Concrete (M) Sdn Bhd, Malaysia. Experimental work and data compilation were assisted by A. Ilham. The first author (M. N. Islam) expresses his sincere gratitude to Dhaka University of Engineering and Technology (DUET), Gazipur, Bangladesh, for granting him leave for the research.

\section{References}

Agarwal, S. K. 2006. Pozzolanic activity of various siliceous materials, Cement and Concrete Research 36(9): 17351739. http://dx.doi.org/10.1016/j.cemconres.2004.06.025

ASTM C1017 Standard Specification for Chemical Admixtures for Use in Producing Flowing Concrete. American Society for Testing and Materials (ASTM), 2007. 9 p.

ASTM C192 Standard Practice for Making and Curing Concrete Test Specimens in the Laboratory. American Society for Testing and Materials (ASTM), 2007. 8 p.

ASTM C143 Standard Test Method for Slump of Hydraulic Cement Concrete. American Society for Testing and Materials (ASTM), 2010. 4 p.

ASTM C39 Standard Test Method for Compressive Strength of Cylindrical Concrete Specimens. American Society for Testing and Materials (ASTM), 2010. 7 p.

ASTM C494 Standard Specification for Chemical Admixtures for Concrete. American Society for Testing and Materials (ASTM), 2011. 11 p.

ASTM C150 Standard Specification for Portland Cement. American Society for Testing and Materials (ASTM), 2011. $9 \mathrm{p}$.
ASTM C1072 Standard Test Methods for Measurement of Masonry Flexural Bond Strength. American Society for Testing and Materials (ASTM), 2011. 19 p.

ASTM C33 Standard Specification for Concrete Aggregates. American Society for Testing and Materials (ASTM), 2011. $11 \mathrm{p}$

Bai, J.; Gailius, A. 2009. Consistency of fly ash and metakaolin concrete, Journal of Civil Engineering and Management 15(2): 131-135. http://dx.doi.org/10.3846/1392-3730.2009.15.131-135

Bai, J.; Wild, S.; Ware, J. A.; Sabir, B. B. 2003. Using neural networks to predict workability of concrete incorporating metakaolin and fly ash, Advances in Engineering Software 34(11-12): 663-669. http://dx.doi.org/10.1016/S0965-9978(03)00102-9

Bilim, C.; Atiş, C. D.; Tanyildizi, H.; Karahan, O. 2009. Predicting the compressive strength of ground granulated blast furnace slag concrete using artificial neural network, $A d$ vances in Engineering Software 40(5): 334-340. http://dx.doi.org/10.1016/j.advengsoft.2008.05.005

Bui, D. D. 2001. Rice husk ash as a mineral admixture for high performance concrete. PhD thesis. Delft: Delft University Press.

Chindaprasirt, P.; Kanchanda, P.; Sathonsaowaphak, A.; Cao, H. T. 2007. Sulfate resistance of blended cements containing fly ash and rice husk ash, Construction and Building Materials 21(6): 1356-1361.

http://dx.doi.org/10.1016/j.conbuildmat.2005.10.005

Columna, V. B. 1974. The effect of rice hull ash in cement and concrete mixes. M. Engg. Thesis. Thailand: Asian Institute of Technology.

de Sensale, G. R. 2006. Strength development of concrete with rice-husk ash, Cement and Concrete Composites 28(2): $158-160$.

http://dx.doi.org/10.1016/j.cemconcomp.2005.09.005

de Sensale, G. R.; Ribeiro, A. B.; Gonçalves, A. 2008. Effects of RHA on autogenous shrinkage of Portland cement pastes, Cement and Concrete Composites 30(10): 892-897. http://dx.doi.org/10.1016/j.cemconcomp.2008.06.014

Ganesan, K.; Rajagopal, K.; Thangavel, K. 2008. Rice husk ash blended cement: assessment of optimal level of replacement for strength and permeability properties of concrete, Construction and Building Materials 22(8): 1675-1683. http://dx.doi.org/10.1016/j.conbuildmat.2007.06.011

Gastaldini, A. L. G.; Isaia, G. C.; Gomes, N. S.; Sperb, J. E. K. 2007. Chloride penetration and carbonation in concrete with rice husk ash and chemical activators, Cement and Concrete Composites 29(3): 176-180.

http://dx.doi.org/10.1016/j.cemconcomp.2006.11.010

Giaccio, G.; de Sensale, G. R.; Zerbino, R. 2007. Failure mechanism of normal and high-strength concrete with ricehusk ash, Cement and Concrete Composites 29(7): 566574. http://dx.doi.org/10.1016/j.cemconcomp.2007.04.005

Guang, N. H.; Zong, W. J. 2000. Prediction of compressive strength of concrete by neural networks, Cement and Concrete Research 30(8): 1245-1250. http://dx.doi.org/10.1016/S0008-8846(00)00345-8

Ismail, M. S.; Waliuddin, A. M. 1996. Effect of rice husk ash on high strength concrete, Construction and Building Materials 10(7): 521-526.

http://dx.doi.org/10.1016/0950-0618(96)00010-4

Jaśniok, M.; Zybura, A. 2009. Modelling the carbonated concrete realkalization, Journal of Civil Engineering and Management 15(2): 159-168.

http://dx.doi.org/10.3846/1392-3730.2009.15.159-168 
Jauberthie, R.; Rendell, F.; Tamba, S.; Cisse, I. 2000. Origin of the pozzolanic effect of rice husks, Construction and Building Materials 14(8): 419-423. http://dx.doi.org/10.1016/S0950-0618(00)00045-3

Kamaitis, Z. 2008. Modelling of corrosion protection for reinforced concrete structures with surface coatings, Journal of Civil Engineering and Management 14(4): 241-249. http://dx.doi.org/10.3846/1392-3730.2008.14.23

Kasperkiewics, J.; Racz, J.; Dubrawski, A. 1995. HPC strength prediction using ANN, Journal of Computing in Civil Engineering ASCE 9(4): 279-284. http://dx.doi.org/10.1061/ (ASCE)0887-3801(1995)9:4(279)

Kutner, M. H.; Nachtsheirn, C. J.; Neter, J.; Li, W. 2004. Applied linear regression models. $5^{\text {th }}$ Ed. New York: The McGraw Hill Companies. 984 p.

Lai, S.; Serra, M. 1997. Concrete strength prediction by means of neural network, Construction and Building Materials 11(2): 93-98. http://dx.doi.org/10.1016/S0950-0618(97) $00007-\mathrm{X}$

Lee, S.-C. 2003. Prediction of concrete strength using artificial neural networks, Engineering Structures 25(7): 849-857. http://dx.doi.org/10.1016/S0141-0296(03)00004-X

Lim, C.-H.; Yoon, Y.-S.; Kim, J.-H. 2004. Genetic algorithm in mix proportioning of high-performance concrete, Cement and Concrete Research 34(3): 409-420. http://dx.doi.org/10.1016/j.cemconres.2003.08.018

Mehta, P. K. 1977. Properties of blended cement made from rice husk ash, ACI Materials Journal 74(9): 440-442.

Mehta, P. K. 1989. Rice husk ash as a mineral admixture in concrete, in Proc. of the $2^{\text {nd }}$ International Seminar on Durability of Concrete, Gothenburg, Sweden, 1989, 131136.

Minitab Inc. 2004. MINITAB Release 14, Statistical Software, Minitab Inc.

Nair, D. G.; Fraaij, A.; Klaassen, A. A. K.; Ken-gens, A. P. M. 2008. A structural investigation relating to the pozzolanic activity of rice husk ashes, Cement and Concrete Research 38(6): 861-869. http://dx.doi.org/10.1016/j.cemconres.2007.10.004

Nehdi, M.; Duquette, J.; El Damatty, A. 2003. Performance of rice husk ash produced using a new technology as a mineral admixture in concrete, Cement and Concrete Research 33(8): 1203-1210. http://dx.doi.org/10.1016/S0008-8846(03)00038-3

Özcan, F.; Atiş, C. D.; Karahan, O.; Uncuoğlu, E.; Tanyildizi, H. 2009. Comparison of artificial neural network and fuzzy logic models for prediction of long-term compressive strength of silica fume concrete, Advances in Engineering Software 40(9): 856-863.

http://dx.doi.org/10.1016/j.advengsoft.2009.01.005
Patel, R. 2003. Development of statistical models to simulate and optimize self-consolidating concrete mixes incorporating high volumes of fly ash. MSc thesis. Toronto: Rayerson University.

Saraswathy, V.; Song, H.-W. 2007. Corrosion performance of rice husk ash blended concrete, Construction and Building Materials 21(8): 1779-1784.

http://dx.doi.org/10.1016/j.conbuildmat.2006.05.037

Sarıdemir, M. 2009a. Prediction of compressive strength of concretes containing metakaolin and silica fume by artificial neural networks, Advances in Engineering Software 40(5): 350-355.

http://dx.doi.org/10.1016/j.advengsoft.2008.05.002

Sarıdemir, M. 2009b. Predicting the compressive strength of mortars containing metakaolin by artificial neural networks and fuzzy logic, Advances in Engineering Software 40(9): 920-927. http://dx.doi.org/10.1016/j.advengsoft.2008.12.008

Sata, V.; Jaturapitakkul, C.; Kiattikomol, K. 2007. Influence of pozzolan from various by-product materials on mechanical properties of high strength concrete, Construction and Building Materials 21(7): 1589-1598.

http://dx.doi.org/10.1016/j.conbuildmat.2005.09.011

Simon, M. J. 2003. Concrete mixture optimization using statistical methods: Final Report. Report No. FHWA-RD-03060. McLean: Federal Highway Administration.

Tanyildizi, H. 2009. Fuzzy logic model for the prediction of bond strength of high-strength lightweight concrete, $\mathrm{Ad}$ vances in Engineering Software 40(3): 161-169. http://dx.doi.org/10.1016/j.advengsoft.2007.05.013

Yeh, I.-C. 1998. Modeling of strength of high-performance concrete using artificial neural network, Cement and Concrete Research 28(12): 1797-1808. http://dx.doi.org/10.1016/S0008-8846(98)00165-3

Zain, M. F. M.; Islam, M. N.; Mahmud, F.; Jamil, M. 2011. Production of rice husk ash for use in concrete as a supplementary cementitious material, Construction and Building Materials 25(2): 798-805.

http://dx.doi.org/10.1016/j.conbuildmat.2010.07.003

Zain, M. F. M.; Mahmud, H. B.; Ilham, A.; Faizal, M. 2002. Prediction of splitting tensile strength of highperformance concrete, Cement and Concrete Research 32(8): 1251-1258. http://dx.doi.org/10.1016/S0008-8846(02)00768-8

Zhang, M. H.; Malhotra, V. M. 1996. High-performance concrete incorporating rice husk ash as supplementary cementing material, ACI Materials Journal 93(6): 629-636.

Zia, P.; Ahmad, S.; Leming, M. 1991. High-performance concrete: a state-of-art report. Strategic Highway Research Program, National Research Council, Washington, D.C., (SHRP-C/FR91-103; PB92-130087). 251 p.

Md. Nazrul ISLAM. Prof., Doctor of Civil and Structural Engineering. He works in the Department of Civil Engineering of Dhaka University of Engineering and Technology (DUET), Gazipur, Bangladesh. Research interests: High performance concrete, sustainable construction materials, utilization of waste materials, computer application in civil engineering, expert system.

Muhammad Fauzi Mohd ZAIN. Prof., PhD. He works as a Deputy Dean (Research) in the Faculty of Engineering and Built Environment of the National University of Malaysia (UKM). Research interests: Sustainable construction materials and building systems, high performance concrete.

Maslina JAMIL. Lecturer, PhD. He works in Architecture Department of the National University of Malaysia (UKM). Research interests: Application of artificial neural network, sustainable construction materials and building systems, ecocomposite panels. 